\title{
II. GEOPHYSICAL INVESTIGATIONS AROUND DSDP SITE 251, SOUTHWESTERN INDIAN OCEAN ${ }^{1}$
}

\author{
Bhoopal Naini and John Chute ${ }^{2}$, Lamont-Doherty Geological Observatory of \\ Columbia University,Palisades, New York
}

\begin{abstract}
The southwest branch of the mid-Indian Ocean ridge in the vicinity of DSDP Site 251 is characterized by a northeast-southwest trend that deviates to some extent from the regional structural trend perhaps due to fractures. The free-air gravity field is positive throughout with maximum values similar to the regional maxima. The residual total intensity magnetic field also defines a northeastsouthwest to east northeast-west southwest trend. Seismic reflection profiles reveal the presence of approximately $0.5 \mathrm{~km}$ of poorly stratified, acoustically transparent sediment, ponded in valleys between basement peaks. The sediment distribution pattern forms long linear belts of deposits parallel to the regional structural trend. Basement topography is very rough, made up of isolated peaks and faults and horst-and graben-type features which form narrow elongate ridges that separate the sediment belts.
\end{abstract}

\section{INTRODUCTION}

Lamont-Doherty Geological Observatory conducted a detailed marine geophysical survey of a $1^{\circ} \times 1^{\circ}$ area over the southwest Indian Ocean ridge (SWIR). This survey was carried out on R/V Robert D. Conrad (Cruise 14, February 1971) to choose a possible drilling site for the Deep Sea Drilling Project. Selection of the survey area was made on the basis of an earlier reconnaissance survey made by R/V Vema, Cruise 24 . The location of the survey and details of ships' track and site location are shown in Figures 1 and 2. Subsequently in September 1972, this site was drilled (Site 251, Leg 26 DSDP, Luyendyk, Davies, et al., 1973).

The area of study is located east of Madagascar Ridge and about $200 \mathrm{~km}$ north of the SWIR crest (Figure 1). The area where the Madagascar Ridge joins the Southwest Branch (SWB) has a highly fractured relief associated with the tectonics of these ridges. West of this point the SWB is offset in a sinistral sense by a prominent north-south fracture zone named Malagasy Fracture Zone (Heezen and Tharp, 1965). The distribution of shallow earthquake epicenters (Barazangi and Dorman, 1969) over the SWB of the mid-Indian Ocean ridge implies that it is an active spreading center. McKenzie and Sclater (1971) in their magnetic anomaly identification scheme for the Indian Ocean could not identify any of the known magnetic anomalies of Heirtzler et al., (1968) time scale in this region. However, Schlich and Patriat (1971) have published

\footnotetext{
'Lamont-Doherty Geological Observatory Contribution No. 2035.

${ }^{2}$ Also at Herbert H. Lehman College, The City University of New York, Bronx, N.Y.
}

magnetic profiles across the SWB of the mid-Indian Ocean ridge wherein they identify the axial anomaly and a history of spreading up to 15 m.y.B.P. They suggest that the rate of spreading here cannot be greater than 0.9 $\mathrm{cm} / \mathrm{yr}$. The slow spreading rates and numerous fractures make this a complicated region to study.

\section{TOPOGRAPHY}

Corrected bathymetric soundings in the study area are contoured at 100-meter intervals (Figure 3). Total topographic relief in this area is of the order of 1400 meters. The overall topography seems to represent a complicated pattern made up largely of northeastsouthwest trending features. In the north a narrow northeast-southwest trend is conspicuous. This trend is the same as the regional trend of topography as presented in the bathymetric charts of the Indian Ocean (Fisher, 1973). The 3500- and 3600-meter contours cross the area diagonally, breaking the continuity of regional trend and forming a local northwest-southeast trending pattern as noticed in the southeastern corner of the area (Figure 3).

\section{GRAVITY}

The free-air gravity anomalies for the survey area are contoured at 5-mgal intervals and presented in Figure 4. The free-air field over the entire area is positive with values ranging between +15 and +80 mgal. A north northwest-south southeast to northwest-southeasttrending local pattern is defined by an isolated maximum and minimum in the central part of the area. Towards north the local anomaly pattern forms a northeast-southwest-trending pattern which is similar to that of the regional free-air gravity anomaly pattern presented by Talwani and Kahle (in press). It is believed 


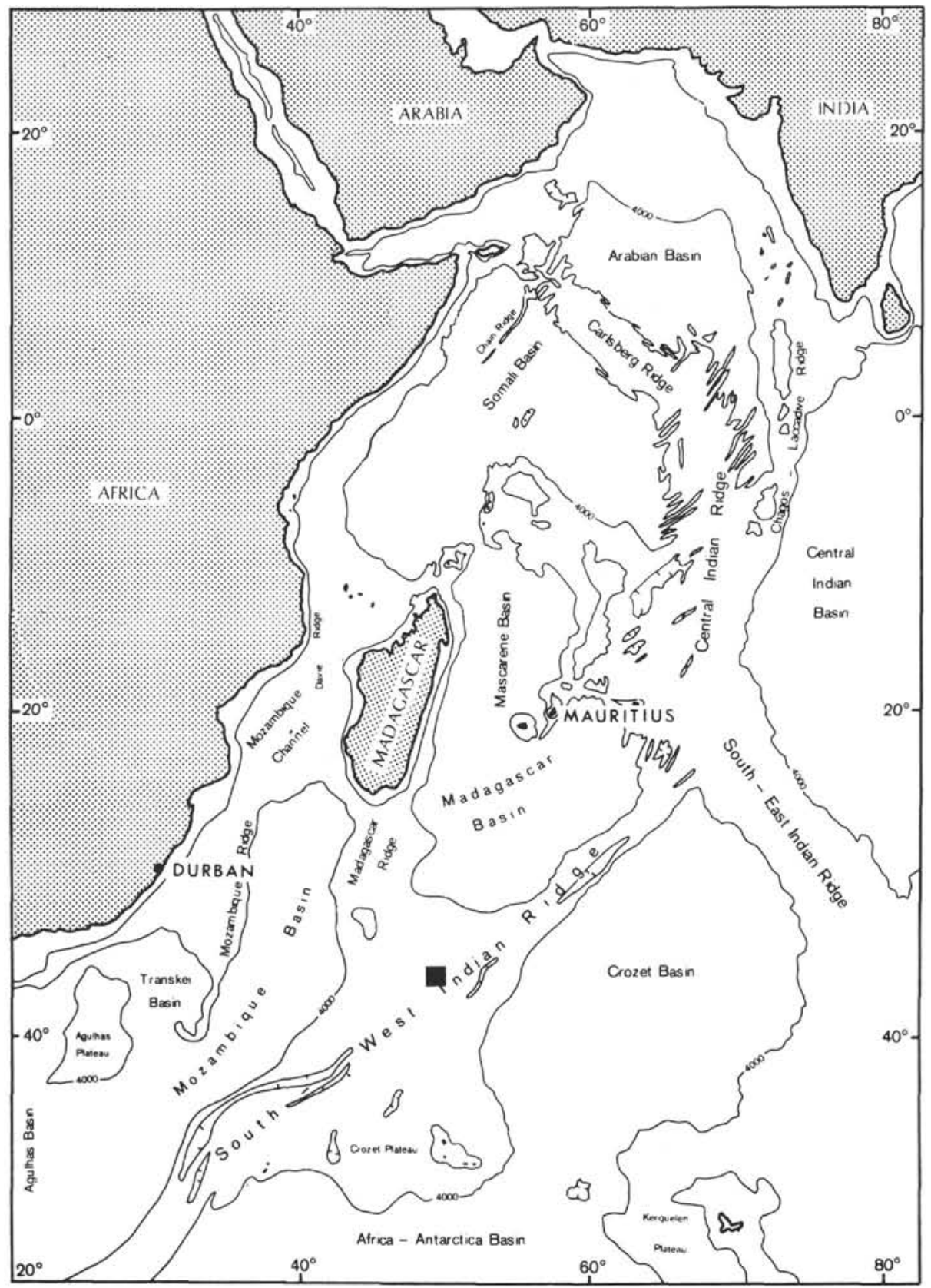

Figure 1. Generalized bathymetric map of the western Indian Ocean, with major topographic features outlined by 4000-meter isobath, and the survey site located as a black square.

that among other ridges of the southwest Indian Ocean the Madagascar and the SWB present largest positive anomalies with values of up to $+80 \mathrm{mgal}\left(1^{\circ} \times 1^{\circ}\right.$ average value) (Kahle and Talwani, in press). This fact is shown in the northwestern part of the survey area where the free-air gravity anomalies reach values of about +80 mgal.

\section{MAGNETICS}

The residual total intensity magnetic anomalies in the study area are plotted along the ship's track and contoured at $50 \gamma$ intervals (Figure 5). The trend of the contours seems to define a definite northeast-southwest to east northeast-west southwest pattern. There is no published account of magnetic anomaly identifications in this region. McKenzie and Sclater (1971) in their magnetic anomaly identifications for the Indian Ocean show only the axis of the ridge as defined by earthquake epicenters. However, Schlich and Patriat (1971) have published magnetic profiles in the vicinity of this area, in which they identify the axial anomaly and anomalies extending up to 15 m.y.B.P. on the magnetic time scale of Heirtzler et al. (1968). Their model suggests a spreading rate of $0.6 \mathrm{~cm} / \mathrm{yr}$ and they conclude that the 


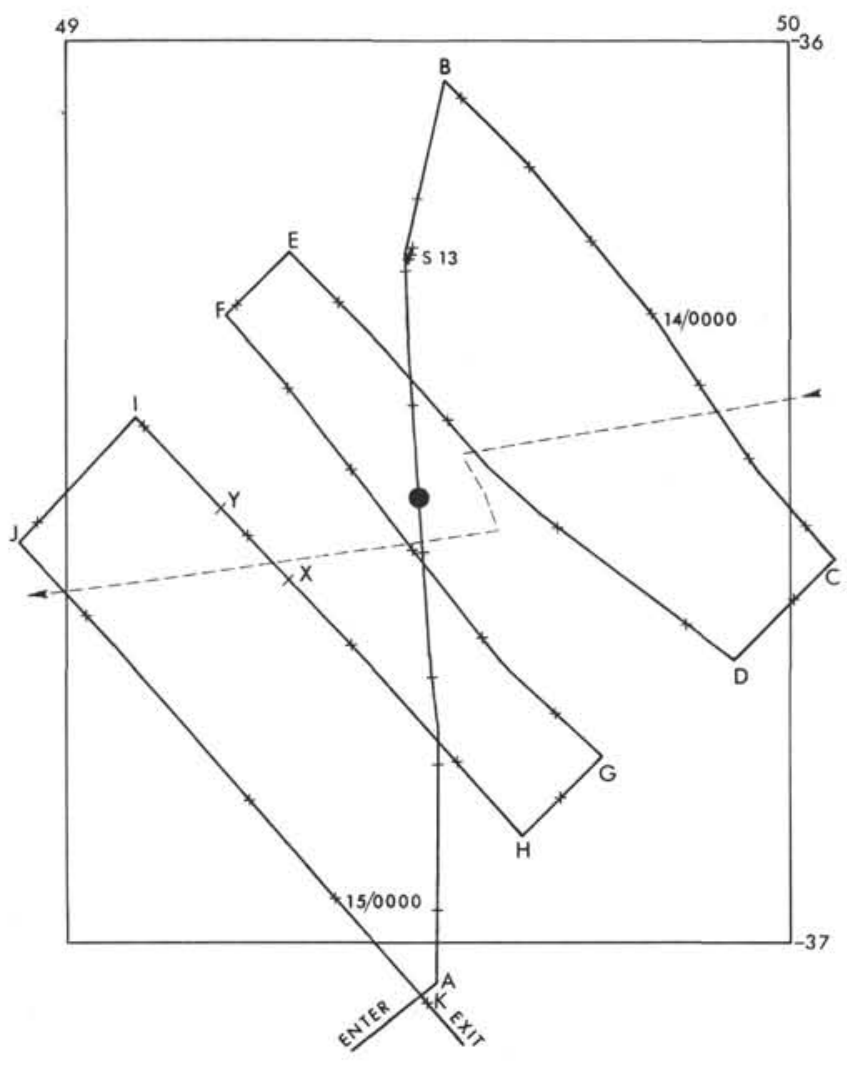

Figure 2. Track synopsis for the site survey. Plus marks represent time every hour on the hour; satellite fixes once a day marked with day and time. Number with prefix "s" corresponds to ship's station. $A B, C D$, etc. locate seismic reflection profiles of Figures 6 and 7. Black circle is location of Site 251. Dotted line is Vema-24 track (0700-1658 Sept. 29, 1967).

spreading may not have been any faster than $0.9 \mathrm{~cm} / \mathrm{yr}$. With such extremely low rates of spreading and the complicated pattern of topography, it is impossible to identify individual anomalies in this area.

\section{SEISMIC REFLECTION PROFILING}

Seismic reflection profiles along the ship's track are presented in Figure 6a-f. It is seen that this area is covered with poorly stratified acoustically transparent sediment. Definite layering cannot be assigned to these sediments. Sediment is underlain by basement which can be traced throughout the entire area. The nature of the basement is very rough, with isolated peaks and faults, and horst- and graben-like features. Evidence of faulting is also reflected by the sediments. Small-scale roughness of the sea floor is evidenced by the hyperbolated reflections on the $3.5-\mathrm{kHz}$ echo-sounder records (Figure 7).

Thickness of sediment in terms of two-way vertical reflection time was plotted at 10 -min intervals along the ship's track and contoured at 0.1 -sec intervals in Figure $8(0.1 \mathrm{sec}$ two-way vertical reflection time corresponds to $100 \mathrm{~m}$ in thickness, assuming a mean velocity of 2.0 $\mathrm{km} / \mathrm{sec}$ ). Sediment thickness in this area varies between 0 and $0.5 \mathrm{sec}$. Most of the sediment is confined to major

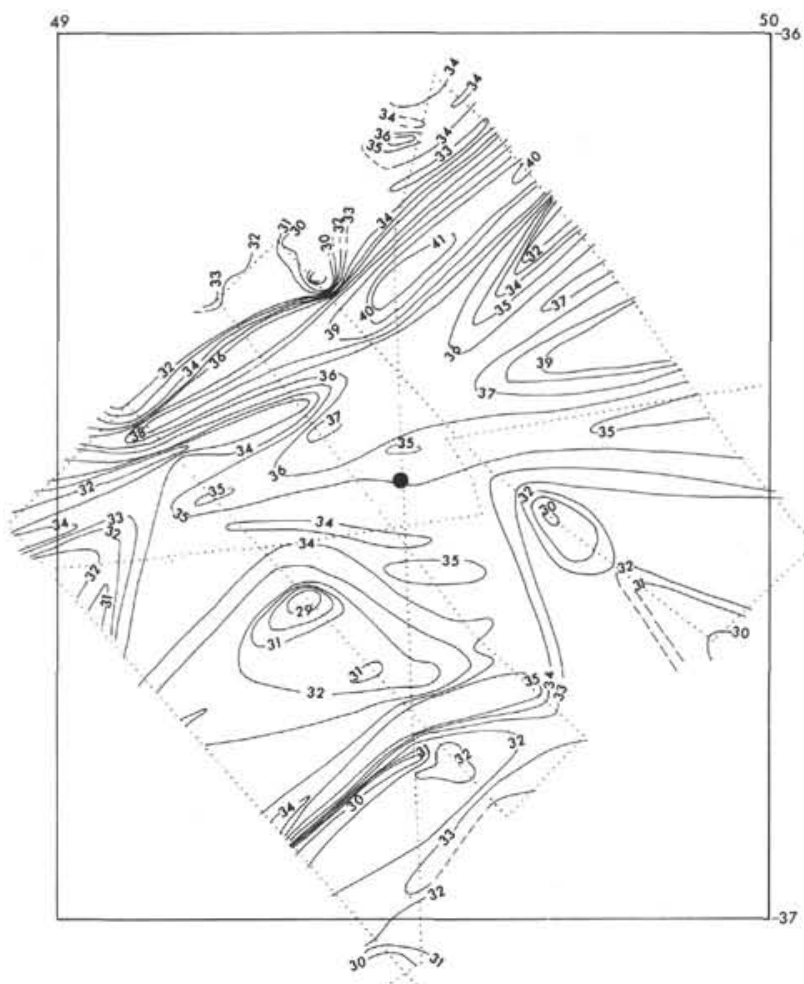

Figure 3. Bathymetric chart of the survey area. Bathymetric soundings in corrected meters contoured at 100-meter intervals. Black circle is location of Site 251.

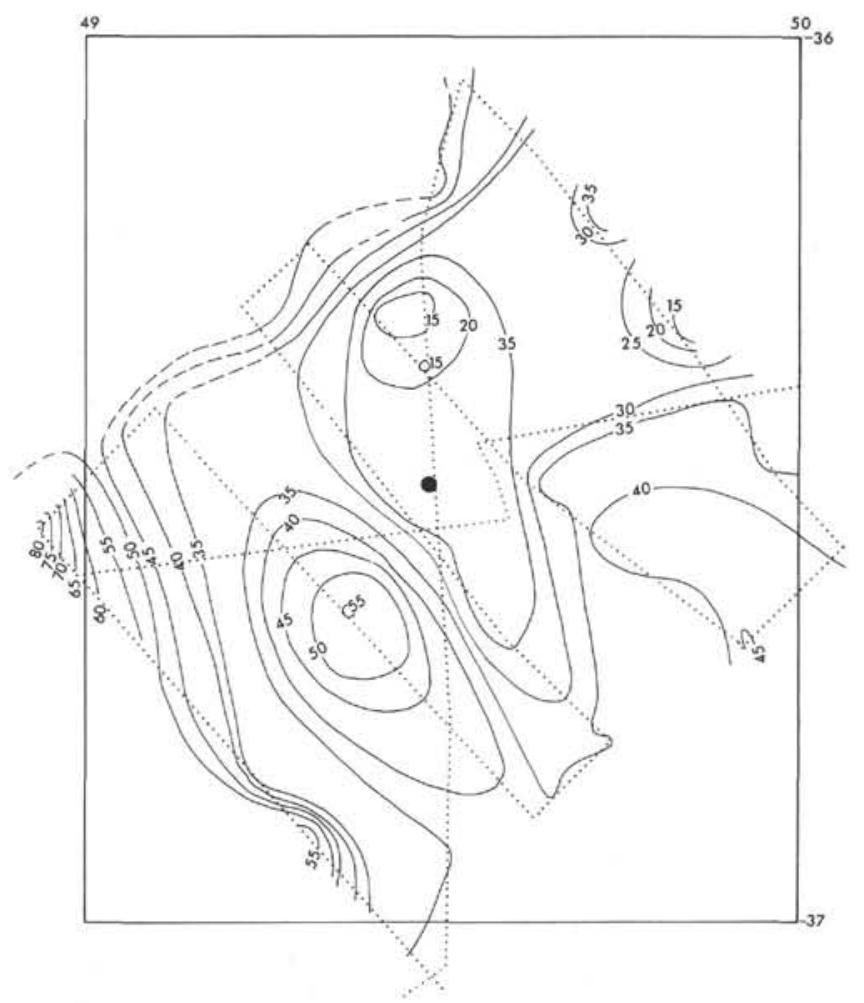

Figure 4. Free-air gravity anomalies in the survey area contoured at 5-mgal intervals. Black circle is location of Site 251. 


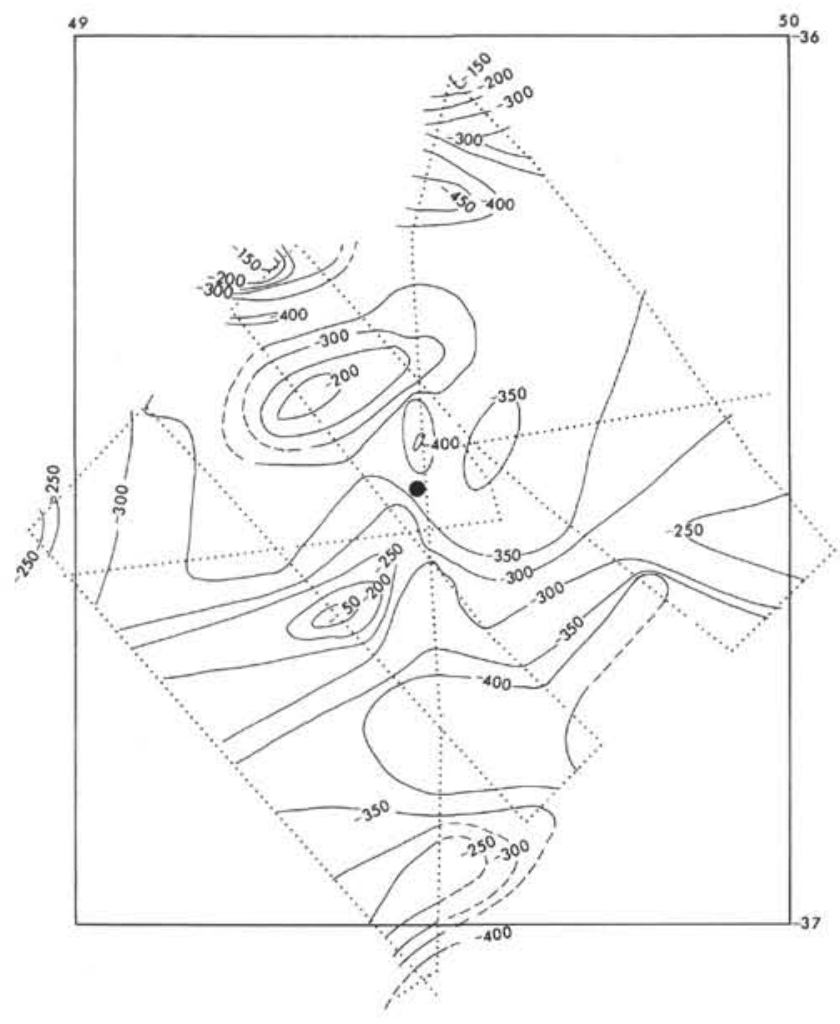

Figure 5. Total intensity residual magnetic anomalies contoured at $50 \gamma$ intervals. Site 251 is located by black circle.

basement depressions and small pockets between basement peaks. However, the overall sediment distribution pattern represents linear northeast-southwest-trending belts of sediment between basement ridges. The basement ridges are linear but locally discontinuous, suggesting the possible existence of fractures that run approximately perpendicular to the trends of the local sediment distribution and regional topography in the area of survey.

\section{BOTTOM SAMPLING}

A piston core was collected at station 13 (see Figures 2 and $6 \mathrm{a})$. The $606-\mathrm{cm}-\mathrm{long}$ core consisted of foraminiferal marl ooze, foraminiferal marl. The carbon content was moderate. It contained coarse fraction made up of planktonic foraminifera, with sponge spicules, Radiolaria, dark minerals, benthonic foraminifera, echinoid spines, shell fragments, and quartz. Dating of the foraminifera has yielded Pleistocene age for this core (T. Saito, personal communication).

\section{CONCLUSIONS}

This study of the SWB of the mid-Indian Ocean ridge has revealed that:

1) The local topographic trends deviate from the northeast-southwest regional trend to some extent possibly due to the presence of cross-fractures.

2) The free-air gravity anomaly field is positive throughout the area and forms part of the regional gravity high in this region.
3) The residual total intensity magnetic field defines a northeast-southwest to east northeast-west southwest pattern.

4) The topography of the sea floor is very rough, often giving rise to reflection hyperbolas in seismic and echo-sounding records.

5) Basement topography is very rough often representing isolated peaks, linear ridges, faults, and horst- and graben-like features.

6) Seismic reflection profiles indicate the presence of poorly stratified, acoustically transparent sediment that is found in pockets in the basement depressions over the entire area.

7) The sediment is distributed in narrow linear belts trending parallel to the local and regional structural trend. These linear sediment belts are separated by narrow linear basement ridges that are locally discontinuous, perhaps due to fracturing and faulting.

\section{ACKNOWLEDGMENTS}

We thank Dr. Jeffrey Weissel and Mr. Charles Windisch for critical review of the manuscript. We are grateful to Mr. John Ewing for encouragement given in carrying out this work. Thanks are also due to the officers and crew of the R/V Conrad, in particular to Dr. Eric Simpson of the University of Cape Town, South Africa, for participation as a visiting scientist; and Miss Betty Batchelder for editorial help.

This work was supported by Grants GA 27281 and GA 28338 from the National Science Foundation and the Office of Naval Research Contract N00014-67-A-0108-0004.

\section{REFERENCES}

Barazangi, M. and Dorman, J., 1969. World seismicity maps compiled from ESSA, Coast and Geodetic Survey, epicenter data, 1961-1967: Seism. Soc. Am. Bull., v. 59, p. 369-380.

Fisher, R. L., in press. Bathymetric charts of the Indian Ocean. In Udintsev, G. (Ed.), IIOE Atlas Geol. Geophys.

Heezen, B. C. and Tharp, M., 1965. Physiographic diagram of the Indian Ocean, the Red Sea, the South China Sea, the Sulu Sea and the Celebes Sea with descriptive sheet: New York (Geol. Soc. Am.).

Heirtzler, J. R., Dickson, G. O., Herron, E. M., Pitman, W. C., and Le Pichon, X., 1968. Marine magentic anomalies, geomagnetic field reversals, and motions of the ocean floor and continents: J. Geophys. Res., v. 73, p. 2119-2136.

Kahle, H. G. and Talwani, M., 1973. Gravimetric Indian Ocean geoid: Z. Geophys., v. 39, p. 167-187.

Luyendyk, B. P., Davies, T. A., Rodolfo, K. S., Kempe, D. R. C., McKelvey, B. C., Leidy, R. D., Horvath, G. J., Hyndman, R. D., Theirstien, H. R., Boltovskoy, E., and Doyle, P., 1973. Deep Sea Drilling Project, Across the southern "Indian Ocean aboard Glomar Challenger: Geotimes, v. 18, p. 16-19.

McKenzie, D. and Sclater, J. G., 1971. The evolution of the Indian Ocean since the Late Cretaceous: Roy. Astron. Soc. Geophys. J., v. 25, p. 16-19.

Schlich, R. and Patriat, P., 1971. Mise en évidence d'anomalies magnétiques axiales sur la branche ouest de la dorsale médio-indienne: Note Phys. Globe, Sér. D, C. R. Acad. Sci., Paris, v. 272 , p. 700-703.

Talwani, M. and Kahle, H. G., in press. Free-air gravity maps in the Indian Ocean. In Udintsev, G. (Ed.), IIOE Atlas Geol. Geophys. 

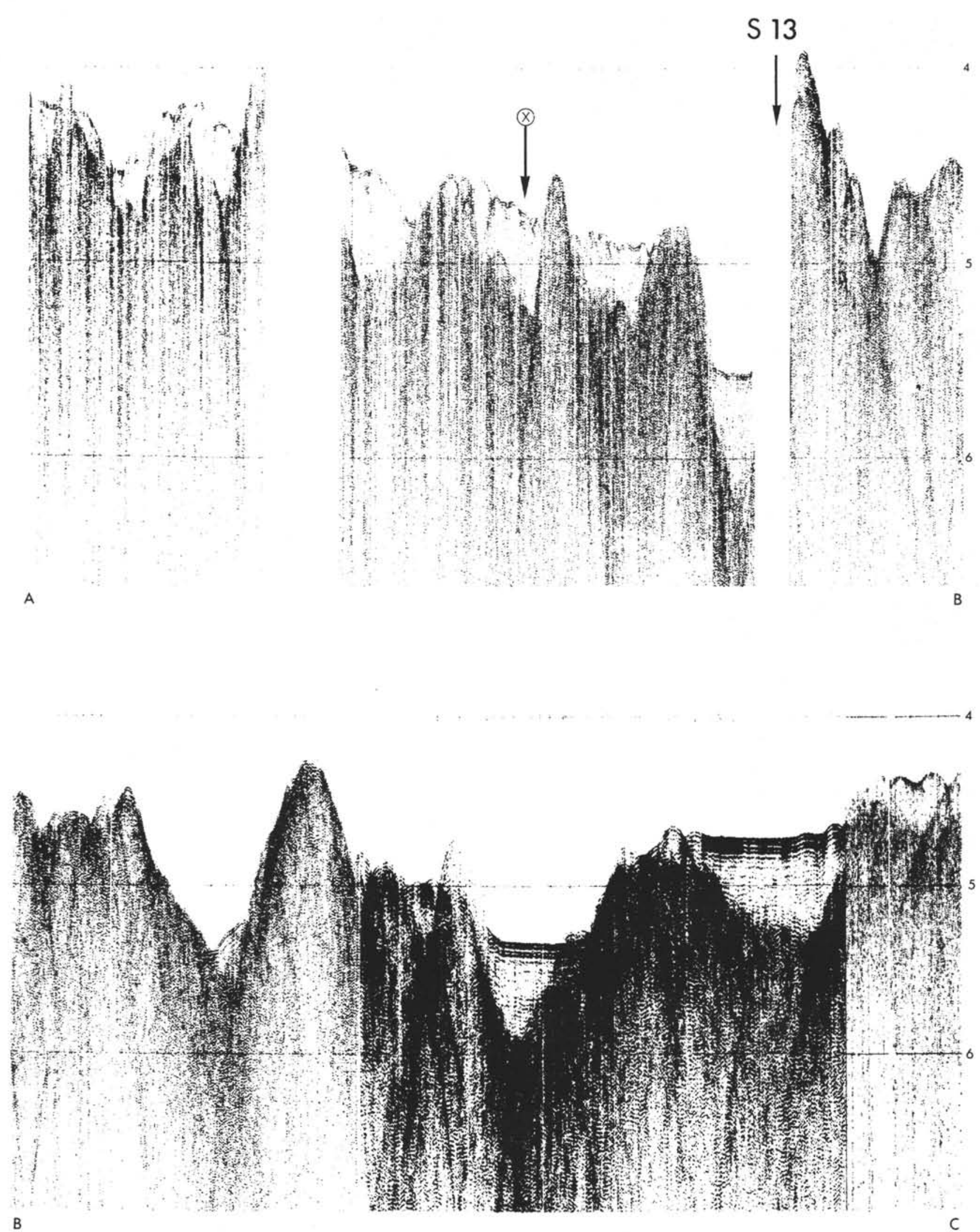

Figure 6. Low-frequency airgun seismic reflection profiles along different sections (Figure 2) showing various features described in the text. Vertical scale is two-way reflection time in seconds. Site 251 is located approximately 500 meters west of the arrow with circle in (a). 

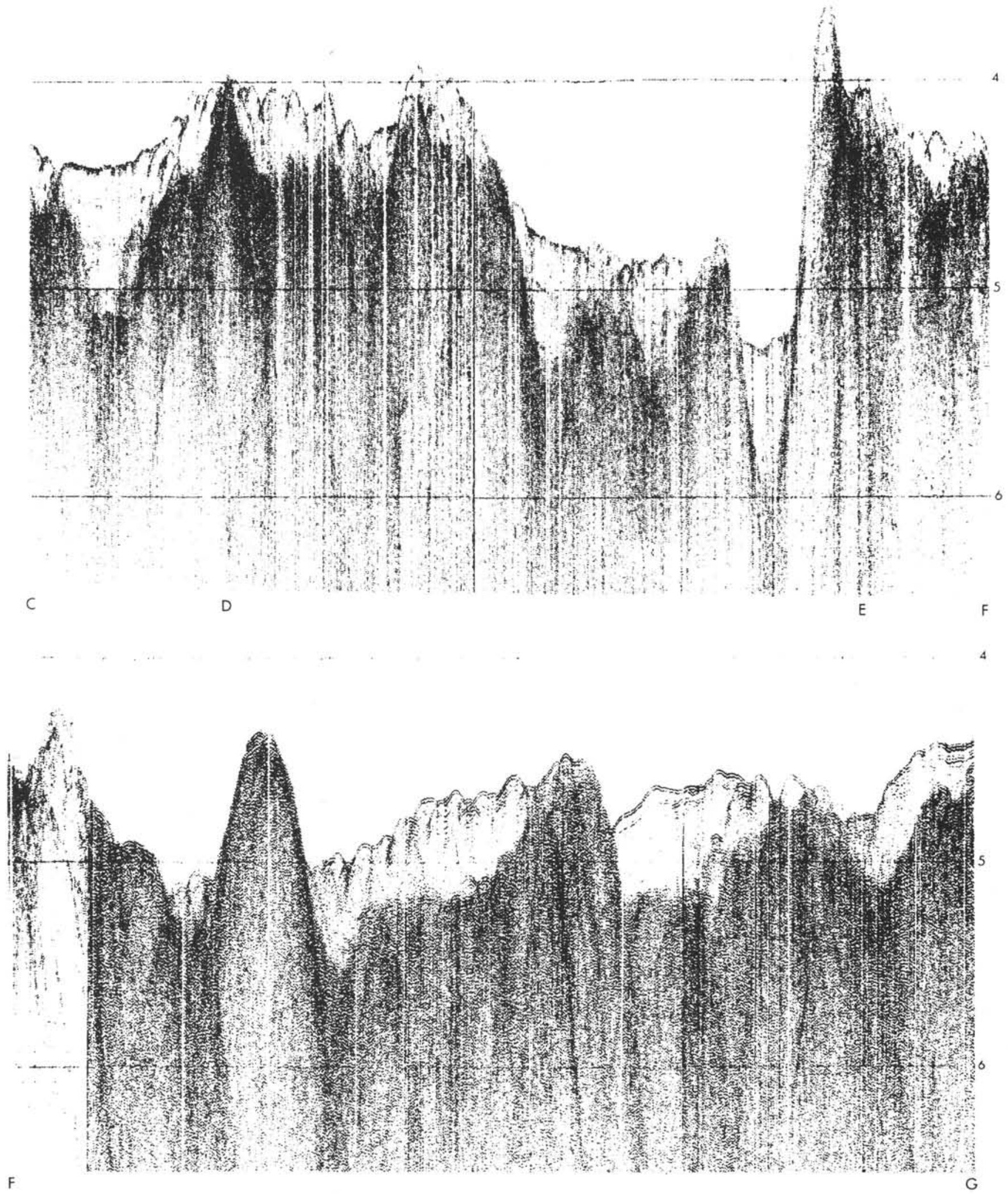

Figure 6. (Continued). 

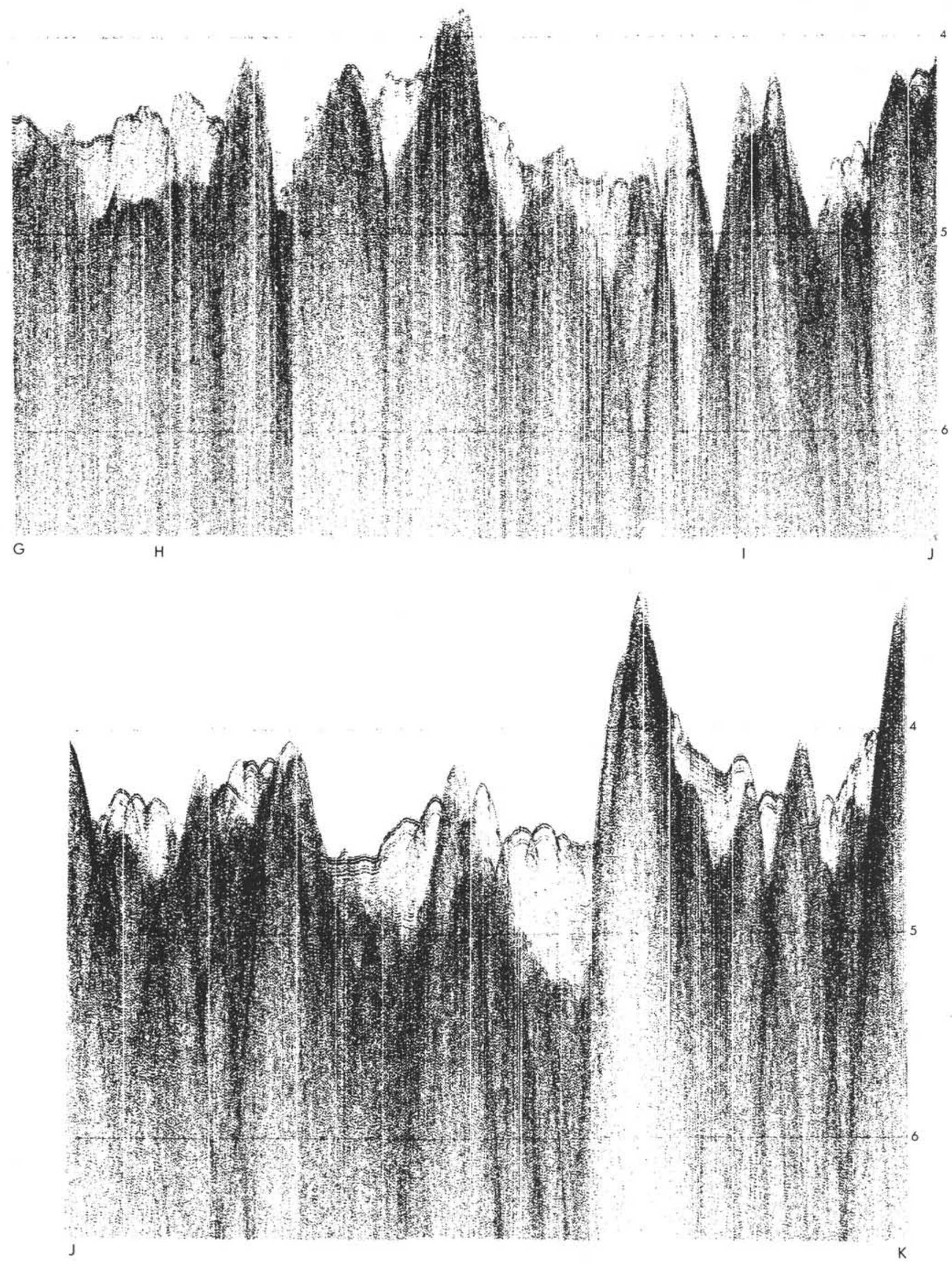

Figure 6. (Continued). 


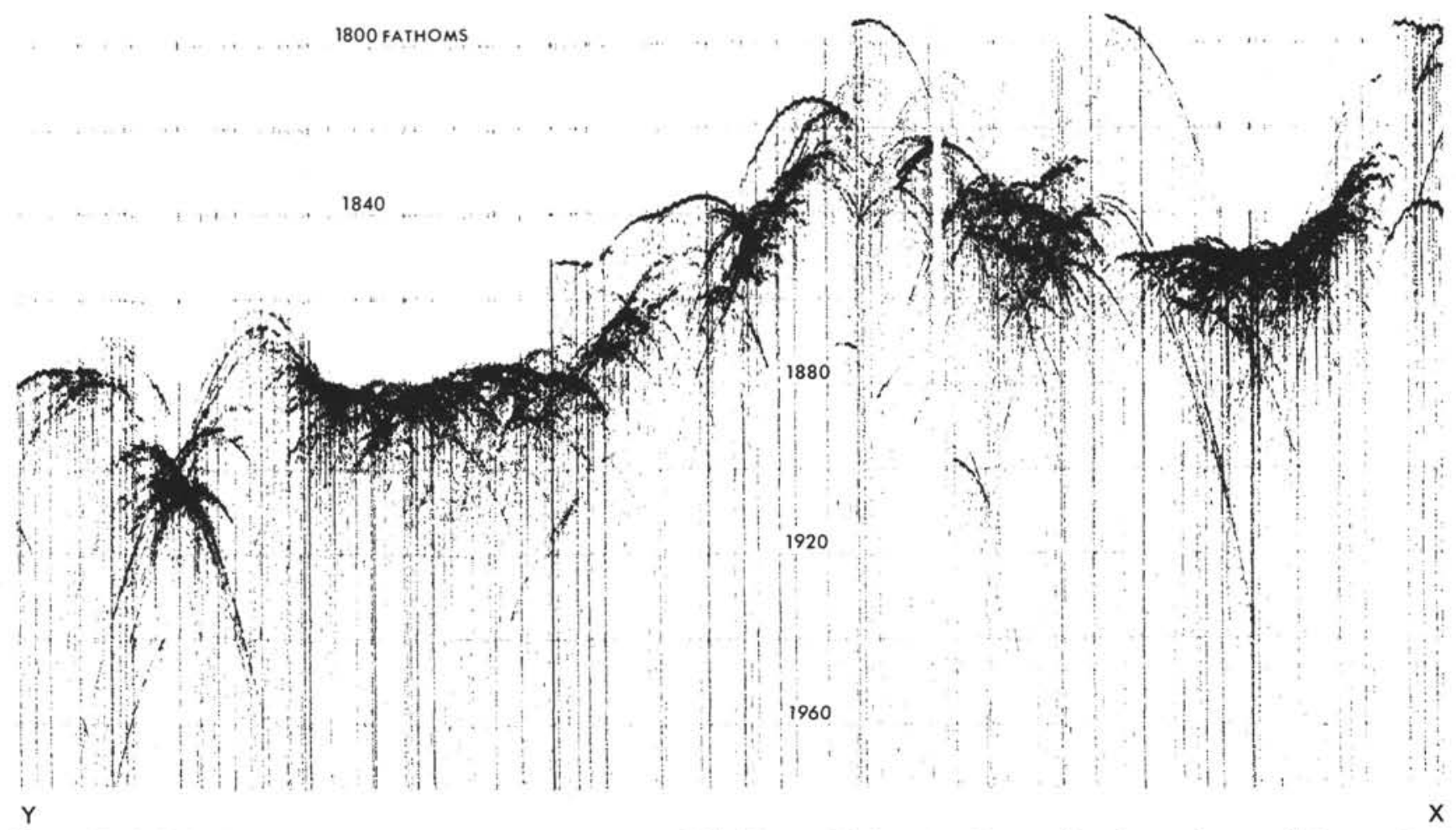

Figure 7. A 3.5-kHz echo-sounder record along section XY (Figure 2) showing the small-scale roughness of the sea floor.

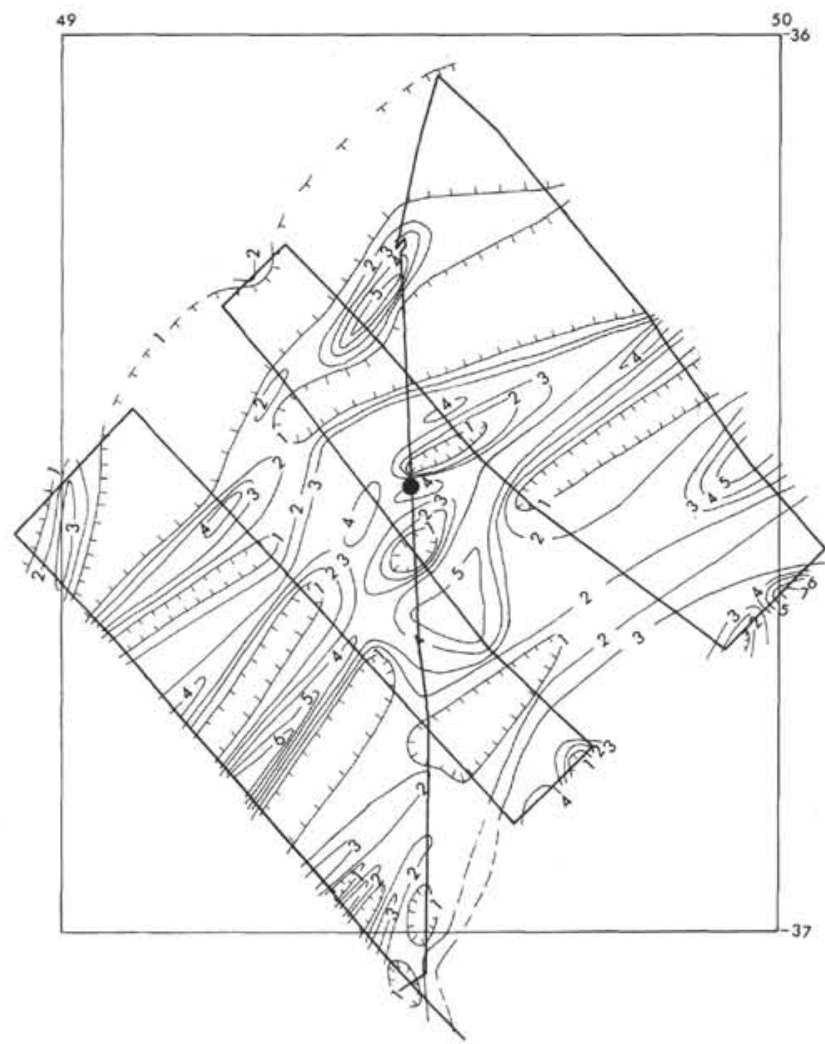

Figure 8. Sediment isopach map of survey area based on two-way travel time through sediment, read at 10-min. intervals and contoured at 0.1-sec. intervals. Hachures are towards basement outcrops. Black circle locates Site 251. 